\title{
Ice Distribution in 'Earliglow' Strawberry Crowns and Tissue Recovery following Extracellular Freezing
}

\author{
Michele R. Warmund ${ }^{1}$ \\ Department of Horticulture, University of Missouri, Columbia, MO 65211 \\ Additional index words. Fragaria ×ananassa, cold hardiness, winter injury
}

\begin{abstract}
Earliglow' strawberry (Fragaria xananassa Duchesne) plants were frozen to -5 or $-50 \mathrm{C}$ to examine the distribution of ice in the crowns. Anatomical studies were also performed to characterize tissue growth in a greenhouse at 4, 8, and 15 weeks after freezing to $\mathbf{- 5 C}$. Ice masses observed in fresh crown tissue corresponded to the presence of extracellular tissue voids in specimens fixed for scanning electron microscopy (SEM). Voids were present near the peduncle and adjacent to the vascular system in crown tissue. After plants were grown in the greenhouse, cell division and enlargement were observed near the voids in crowns subjected to -5C. By 15 weeks after freezing, a few small extracellular voids remained in the crowns. Tissue voids were also present in crowns of plants frozen rapidly to -50C and subsequently thawed. Cells in the crown of these plants were intact and did not appear collapsed after exposure to $-50 \mathrm{C}$, a lethal temperature.
\end{abstract}

Two types of freezing mechanisms have been identified in which tissues in overwintering plants tolerate or avoid ice formation (Burke et al., 1976). Certain tissues in buds and stems of some woody plants avoid freezing by deep supercooling to very low temperatures. Intracellular freezing in these plants results in lethal injury. In contrast, tissues in other woody and herbaceous plants survive freezing by tolerating extracellular ice formation. As the temperature drops below the melting point of the cell sap, water migrates from inside cells to extracellular ice. Dehydration stress resulting from extracellular freezing of tissue water causes lethal injury in these plants (Levitt, 1980).

Strawberry plants exposed to sub-lethal temperatures exhibit produce fewer flowers and leaves, and exhibit leaf distortion and early runnering (Marini and Boyce, 1979; Zurawicz and Stushnoff, 1977). Parenchyma cells in the cortex and medulla also exhibit oxidative browning when dormant strawberry crowns are subjected to low temperatures (Angelo, 1939). Marini and Boyce (1977) reported that plants subjected to artificial freezing survived when more than half of the medulla exhibited browning. However, plants that had browning in the vascular tissue did not survive.

Ice formation in the strawberry crown and subsequent recovery and regrowth of these tissues have not been studied. Ashworth et al. (1989) used a freeze-fixation technique developed for scanning electron microscopy to study the location of extracellular ice during freezing in peach [Prunus persica (L.) Batsch] buds. Tissue voids, resulting from extracellular ice formation during freezing, have also been observed in Forsythia (Ashworth, 1990) and Rubus (Warmund et al., 1992) buds, cereal leaves (Pearce, 1988; Pearce and Ashworth, 1992) and crowns (Olien, 1964), and bark tissue of several tree species (Ashworth et al., 1988; Malone and Ashworth, 1991; Wiegand, 1906).

The purpose of this experiment was to examine the distribution of extracellular ice in dormant 'Earliglow' strawberry crowns exposed to -5 or $-50 \mathrm{C}$ and to characterize tissue recovery at 4,8 , and 15 weeks after exposure to sub-lethal temperatures.

Received for publication 8 Sept. 1992. Accepted for publication 26 Dec. 1992. Contribution from the Missouri Agricultural Experiment Station, Journal Series no. 11769. The cost of publishing this paper was defrayed in part by the payment of page charges. Under postal regulations, this paper therefore must hereby be marked advertisement solely to indicate this fact.

'Associate Professor.

\section{Materials and Methods}

'Earliglow' plants were obtained from a commercial nursery and planted at a 30-cm spacing in a Kreldon silty loam soil at the Southwest Missouri Research Station, Mount Vernon. On 29 Oct. 1990, plants were dug before a natural freeze occurred, packed on ice in insulated boxes, transported to the Univ. of Missouri, and stored at $2 \mathrm{C}$ until experiments were performed. Eight strawberry plants were wrapped in moist cheesecloth and aluminum foil. A 0.01-mm-diameter (30-gauge) copper-constantan thermocouple was attached to individual crowns to monitor tissue temperature. Thermocouple output was read on a digital thermometer (Omega Engineering, Inc., Stamford, Conn.). Samples were then placed in a programmable Tenney Jr. freezer (Tenney Engineering, Inc., Union, N.J.) at $0 \mathrm{C}$ for $2 \mathrm{~h}$. Plants were then cooled at $2 \mathrm{C} / \mathrm{h}$ to $-5 \mathrm{C}$ and held at this temperature for $2 \mathrm{~h}$. After the samples were removed from the freezer, crowns were bisected longitudinally with a surgical blade and photographed.

Scanning electron microscope (SEM) studies. Additional plants were frozen to $-5 \mathrm{C}$ as noted or they were frozen to $-50 \mathrm{C}$ at $2.5 \mathrm{C} /$ min and held at this temperature for $2 \mathrm{~h}$. Plants were then thawed at $2 \mathrm{C}$ for $24 \mathrm{~h}$. Eight samples of each treatment and unfrozen crowns were bisected longitudinally and a $7 \times 7-\mathrm{mm}$ portion of tissue in the upper third of the crown was fixed in $3 \%$ glutaraldehyde and $1 \%$ osmium tetroxide $\left(\mathrm{OsO}_{4}\right)$ in 0.1 - $\mathrm{M}$ phosphate buffer (pH 7.0). Tissue was then dehydrated in a graded ethanol series, critical-point-dried, sputter-coated with gold palladium, and examined on a JEOL JSM-35 microscope (JEOL, Peabody, Mass.) operated at $10 \mathrm{kV}$.

A freeze-fixation method described by MacKenzie et al. (1975) was used to examine the distribution of extracellular ice in 'Earliglow' strawberry crowns frozen to $-5 \mathrm{C}$. Roots were excised from eight plants and individual crowns were placed in a test tube with the basal end of the crown in $0.5 \mathrm{ml}$ of distilled water. Test tubes were submerged in an ethanol bath (NESLAB Instruments, Inc., Newington, N.H.) precooled to OC. An ice chip was then placed in the water to initiate ice formation. After 1 hat $0 \mathrm{C}$, crowns were cooled at $2 \mathrm{C} / \mathrm{h}$ to $-5 \mathrm{C}$, held at this temperature for $1 \mathrm{~h}$, and a precooled solution of $8 \%$ formaldehyde $(\mathrm{v} / \mathrm{v})$ was added to the test tubes to preserve the frozen tissue. After 7 days at $-5 \mathrm{C}$, the formaldehyde solution was removed and replaced with $50 \%$ ethanol, which was removed after $30 \mathrm{~min}$. Samples were then placed at room temperature, dehydrated in a graded ethanol series, and 


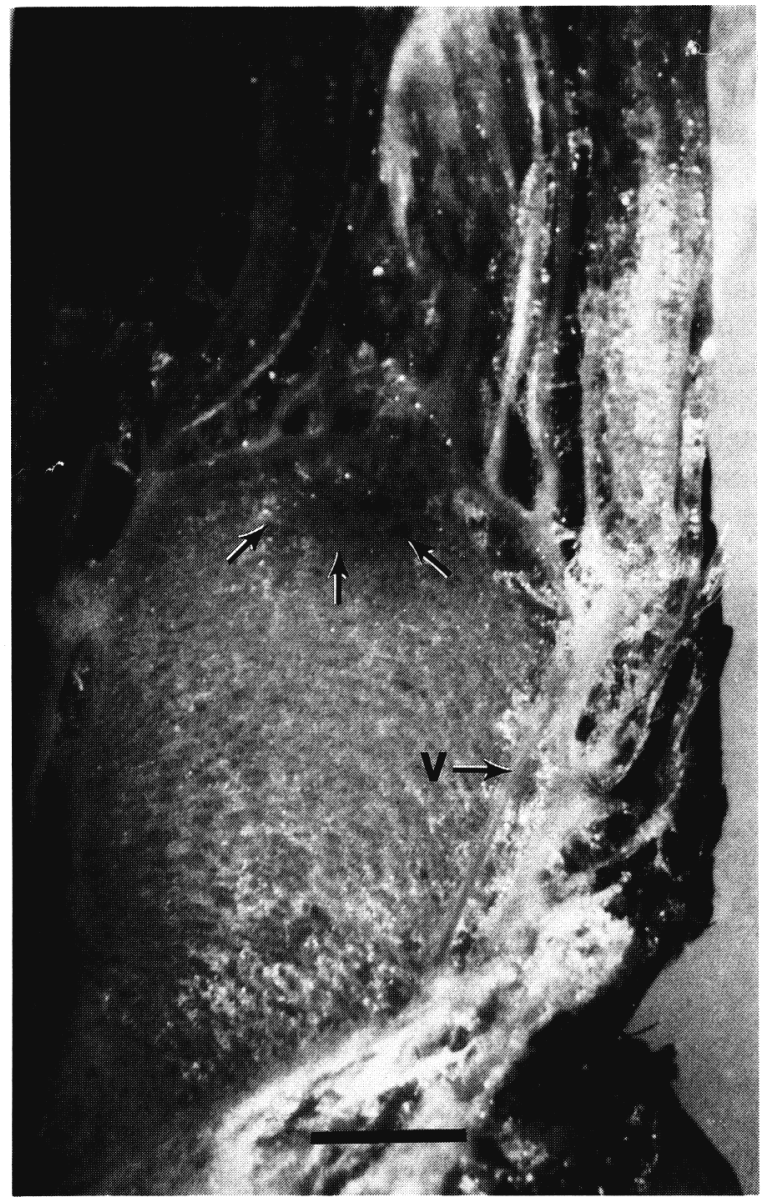

Fig. 1. Strawberry plant that was frozen to $-5 \mathrm{C}$ and bisected immediately after removal from the freezer. Note the ice in the crown near the base of the peduncle (arrows) and adjacent to the vascular (v) tissue. Bar $=0.5 \mathrm{~mm}$. prepared for SEM as described above.

Following these preliminary tests, additional strawberry plants were frozen to $-5 \mathrm{C}$ in the Tenney $\mathrm{Jr}$. freezer, thawed at $2 \mathrm{C}$ for 24 h, planted in Pro-mix BX ( Premier Brands Inc., Stamford, Conn.) in 15-cm-diameter (1.8-liter) pots, and grown in a greenhouse (21C/day and 16C/night). Eight crowns were then prepared for SEM at 4, 8, and 15 weeks after freezing. The diameter of 100 cells per crown was recorded from micrographs $(200 \times)$ of frozen samples at 8 and 15 weeks after freezing to determine if cell enlargement had occurred.

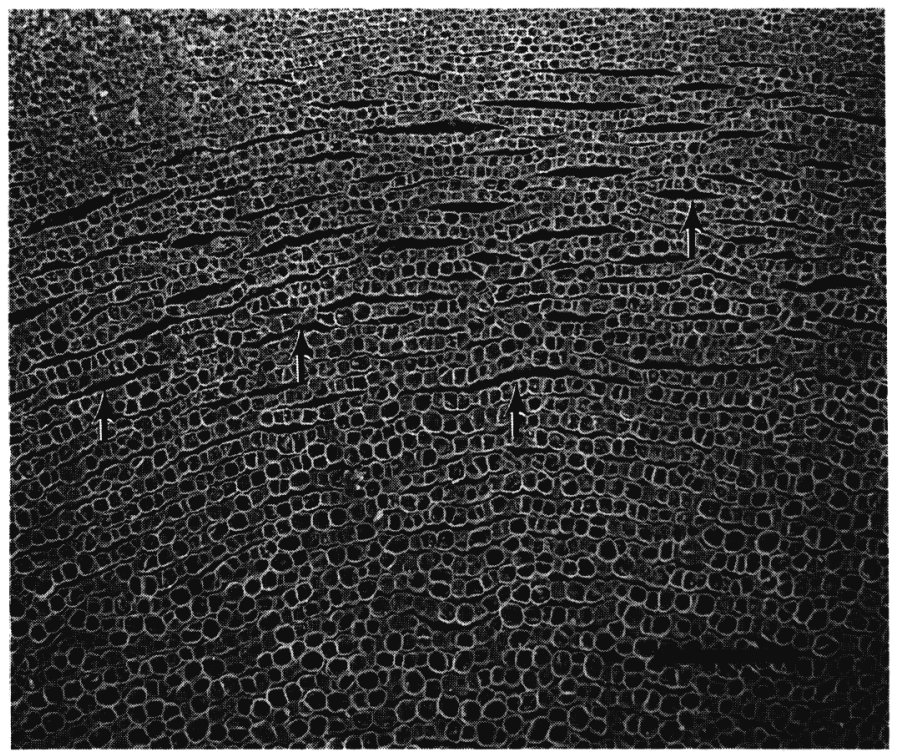

Fig. 3. Extracellular voids (arrows) in a strawberry crown cooled to $-50 \mathrm{C} . \mathrm{Bar}=0.3$ $\mathrm{mm}$.

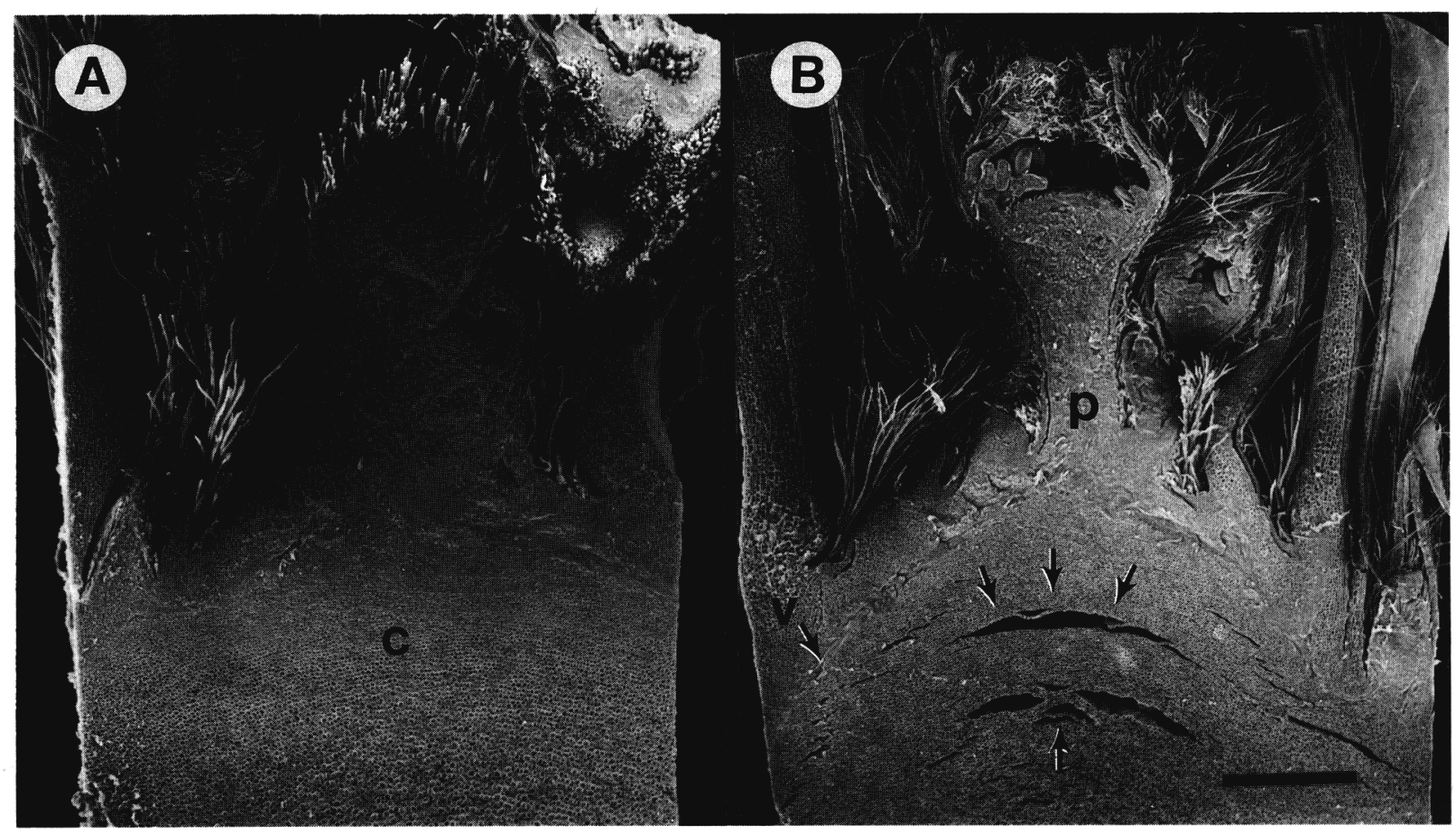

Fig. 2. Scanning electron micrographs of 'Earliglow' strawberry plants fixed in glutaraldehyde. (A) Unfrozen crown (c) tissue with the inflorescence (i). Note the absence of tissue voids. (B) Extracellular voids (arrows) located near the base of the peduncle (p) and adjacent to the vascular (v) tissue in a plant cooled to $-5 \mathrm{C}$ and fixed after thawing at $2 \mathrm{C}$. $\mathrm{Bar}=1 \mathrm{~mm}$. 


\section{Results}

Masses of ice were visible in the fresh crown tissue of strawberry plants immediately after removal from the freezer at $-5 \mathrm{C}$ (Fig. 1). Most of the ice was located in the upper portion of the crown, near the base of the peduncle. Ice was also present in the tissue adjacent to the vascular system. The presence of this ice corresponded to the extracellular voids in the tissue prepared for SEM immediately following freezing (Fig. 2B). Voids in crowns fixed with formaldehyde appeared similar to those fixed with glutaraldehyde and $\mathrm{OsO}_{4}$. Crowns frozen to $-50 \mathrm{C}$ had numerous extracellular voids and the cells in this tissue appeared intact without visible injury (Fig. 3). Voids were absent in crowns of unfrozen control plants (Fig. 2A).
At 4 weeks after freezing, large voids were still visible in crowns of plants frozen to $-5 \mathrm{C}$ (Fig. 4A). However, most of the extracellular voids were confined to the central portion of the crown. Intercellular spaces in crowns examined at 4 weeks after freezing also appeared more compressed or irregular in shape than those examined immediately after freezing.

By 8 weeks after freezing, the extracellular voids appeared smaller (Fig. 4B) than at 4 weeks. Cell division was apparent in unfrozen (Fig. 5A) and frozen crowns (Fig. 5B), as judged by the presence of recently formed anticlinal and periclinal cell walls. The number of cell divisions in a given area could not be quantified accurately in unfrozen or frozen samples due to the varying size of the numerous voids in plants subjected to $-5 \mathrm{C}$. However, the average diameter of cells adjacent to voids was $25 \pm 9 \mu \mathrm{m}$.

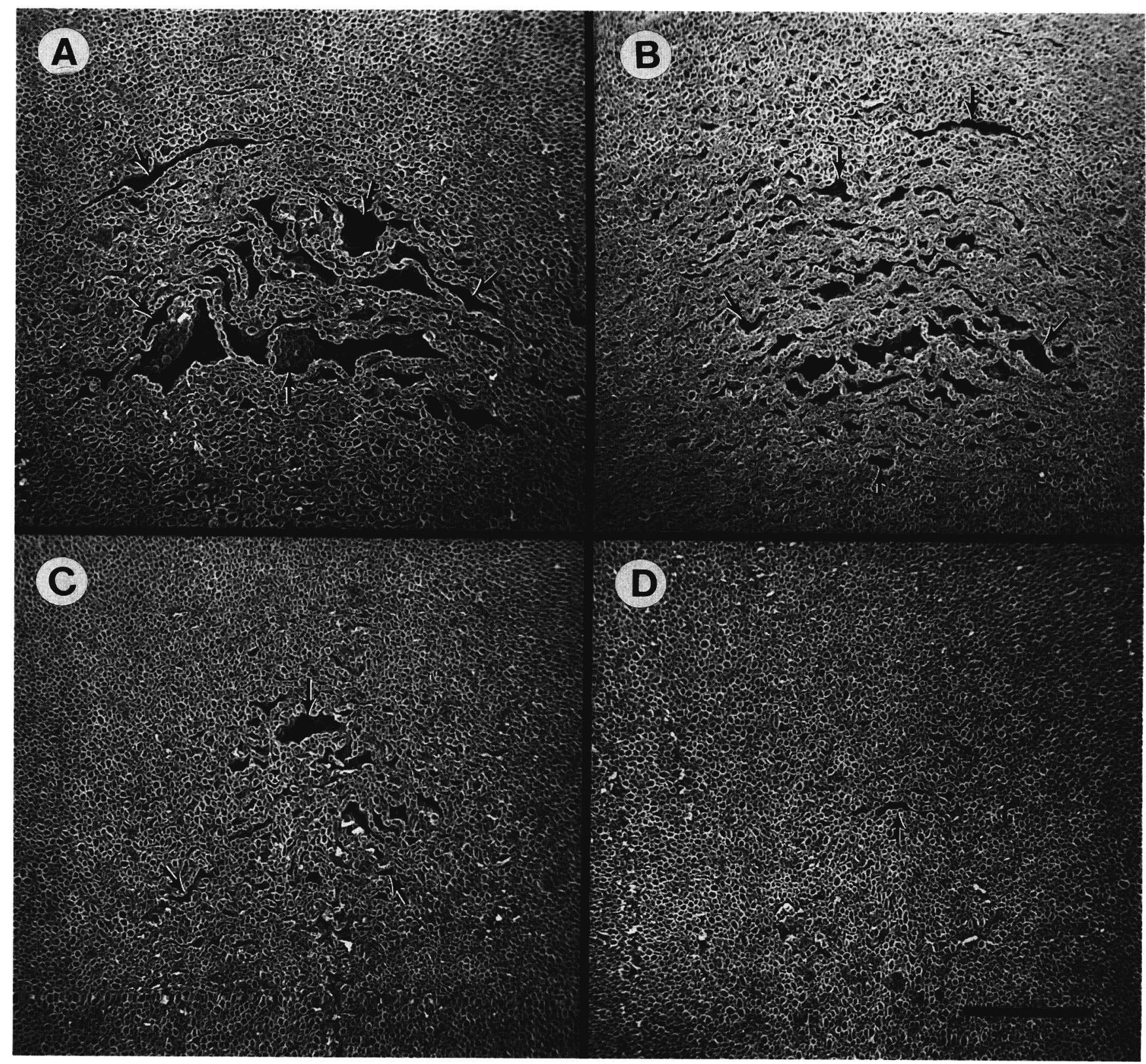

Fig. 4. Scanning electron micrographs of 'Earliglow' strawberry crown tissue of plants cooled to -5C, fixed in formaldehyde, and subsequently grown in the greenhouse. Extracellular voids (arrows) in the crown at (A) $4,(\mathbf{B}) 8$, and (C) 15 weeks after exposure to $-5 C$. (D) Very few voids were visible in three of the crowns examined 15 weeks after freezing. Bar $=1 \mathrm{~mm}$. 


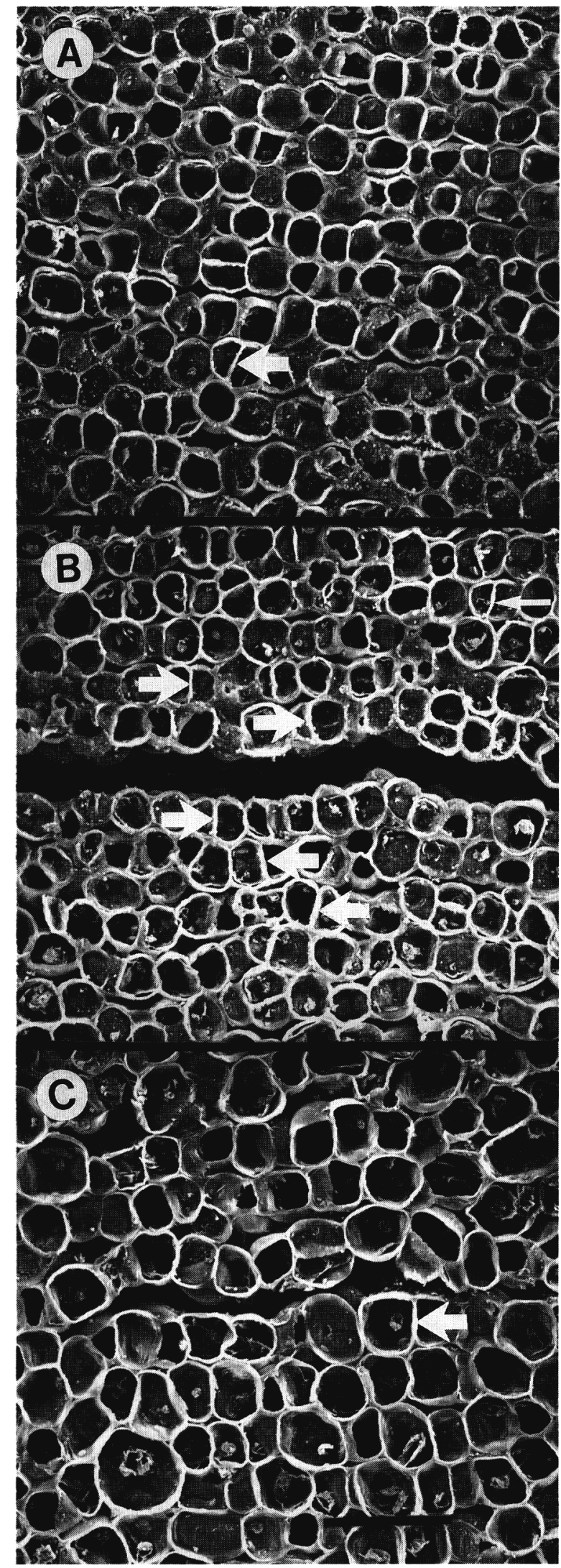

Fig. 5. Crown tissue in 'Earliglow' strawberry plants fixed in formaldehyde. (A) Nonfrozen plant at 8 weeks after exposure to-5C. Extracellular void in the crown of a plant at (B) 8 and (C) 15 weeks after freezing. Note the anticlinal (arrows) cell division and the relative cell size adjacent to the voids. $B a r=0.1 \mathrm{~mm}$.
Small extracellular voids were observed in crowns at 15 weeks after freezing at $-5 \mathrm{C}$ (Fig. 4C). Three of the crowns had very few small voids remaining in the crown tissue (Fig. 4D). The average diameter of cells adjacent to voids was $37 \pm 8 \mu \mathrm{m}$. Most of the plants had developed a branch crown at this sampling date.

\section{Discussion}

Parenchyma cells in 'Earliglow' strawberry crowns were not damaged permanently when exposed to a sub-freezing temperature. All plants exposed to $-5 \mathrm{C}$ resumed growth when planted in the greenhouse after thawing. In a previous study, root regrowth, leaf number, and petiole length of 'Earliglow' plants frozen in a similar manner $(2 \mathrm{C} / \mathrm{h})$ and subsequently grown in the greenhouse for 5 weeks were not reduced at temperatures above -8C (Warmund and $\mathrm{Ki}, 1992)$. The lowest survival temperature of 'Earliglow' plants was $-12 \mathrm{C}$.

In this study, ice formed intercellularly in crown tissue of fresh plant material. The formaldehyde used in the freeze-fixation procedure preserved the voids formed by extracellular ice and indicated that the cells adjacent to the voids did not collapse permanently. Crown tissue fixed with glutaraldehyde followed by $\mathrm{OsO}_{4}$ appeared similar to that fixed in formaldehyde. Thus, extracellular voids were still present after thawing and remained in the crowns for at least 15 weeks after freezing. However, extracellular voids decreased in size as cell division and enlargement occurred in crowns exposed to favorable growing conditions.

Other researchers have reported that water migrates from within cells to extracellular space as the temperature drops below the melting point of the cell sap (Burke et al., 1976; Ishikawa and Sakai, 1982). As cellular water is redistributed to extracellular ice, cellular contraction occurred (Johansson and Krull, 1970; Levitt, 1980). Gusta et al. (1982) suggested that, as the critical temperature is reached, the plasma membrane of dehydrated, collapsed cells undergoes a phase transition, resulting in a loss of semipermeability. Cell walls of brome grass (Bromus sp.) from suspension culture collapsed when frozen to a critical freezing temperature $(-20 \mathrm{C})$ and did not retain their original shape when thawed. Collapsed cortical cells along the margins of extracellular voids have also been observed in the bark of trees (Ashworth et al., 1988; Malone and Ashworth, 1991). Although cell volume was not measured at $-5 \mathrm{C}$ in strawberry crowns, cellular contraction occurred most likely during extracellular freezing. Cellular collapse was not apparent in crowns frozen rapidly to a lethal temperature (-50C) and subsequently thawed. Thus, ice may have formed intracellularly due to the rapid cooling rate and cellular integrity was retained upon thawing.

The reason for the localization of ice near the base of the peduncle and the vascular tissue in strawberry plants is unclear. However, the segregation of extracellular ice has been reported in dormant floral buds of woody plants that supercool. Ice localization in these tissues may be caused by the lower osmotic potential of the floral primordium as compared to adjacent tissues (Quamme and Gusta, 1987), tissue barriers in the bud axis (Quamme, 1978), bud morphology and vascular differentiation (Ashworth, 1984; Ashworth et al., 1989), or the presence of intrinsic ice nucleators (Andrews et al., 1986). Whether these factors influence extracellular ice formation in herbaceous plants that tolerate freezing is unknown.

In conclusion, extracellular ice formation at $-5 \mathrm{C}$ did not injure strawberry plants permanently, although crown structure was disrupted temporarily. Extracellular ice was observed in strawberry crowns near the base of the peduncle and adjacent to the 
vascular system when exposed to sub-lethal temperatures. Although voids formed from extracellular ice remained in the tissue after thawing, the number and size of the voids had been reduced considerably by 15 weeks after freezing when plants were grown in the greenhouse. Cell division and enlargement occurred near the tissue voids in crowns during this time and a branch crown had also developed on most of the plants.

\section{Literature Cited}

Andrews, P.K., E.L. Proebsting, Jr., and D.C. Gross. 1986. Ice nucleation and supercooling in freeze-sensitive peach and sweet cherry tissues. J. Amer. Soc. Hort. Sci. 111:232-236.

Angelo, E. 1939. Factors relating to hardiness in the strawberry. Part 1. Development of cold resistance in strawberry varieties. Minn. Agr. Expt. Sta. Tech. Bul. 135.

Ashworth, E.N. 1990. The formation and distribution of ice within forsythia flower buds. Plant Physiol. 92:718-725.

Ashworth, E.N. and G.A. Davis. 1984. Ice nucleation within peach trees. J. Amer. Soc. Hort. Sci. 109:198-201.

Ashworth, E.N., G.A. Davis, and M.E. Wisniewski. 1989. The formation and distribution of ice within dormant and deacclimated peach flower buds. Plant Cell Environ. 12:521-528.

Ashworth, E.N., P. Echlin, R.S. Pearce, and T.L. Hayes. 1988. Ice formation and tissue response in apple twigs. Plant Cell Environ. 11:703-710.

Burke, M.J., L.V. Gusta, H.A. Quamme, C.J. Wiser, and P.H. Li. 1976. Freezing and injury in plants, p. 507-528. In: W.R. Briggs, P.B. Green, and R.L. Jones (eds.). Annu. Rev. Plant Physiol., Annual Reviews Inc., Palo Alto, Calif.

Gusta, L.V., D.B. Fowler, and N.J. Tyler. 1982. Factors influencing hardening and survival in winter wheat, p. 23-40. In: P.H. Li and A Sakai (eds.). Plant cold hardiness and freezing stress. vol 2. Academic, New York.

Ishikawa, M. and A. Sakai. 1982. Characteristics of freezing avoidance in comparison with freezing tolerance: a demonstration of extraorgan freezing, p. 325-340. In: P.H. Li and A. Sakai (eds.). Plant cold hardiness and freezing stress: mechanisms and crop implications. vol. 2. Academic, New York.

Johansson, N.O. and E. Krull. 1970. Ice formation, cell contraction and frost killing of wheat plants. Natl. Swedish Inst. Plant Protect. Contr. 14:343-362.

Levitt, J. 1980. Responses of plants to environmental stresses. Vol. I. Chilling, freezing, and high temperature stresses. 2nd ed. Academic, New York.

MacKenzie, A.P., T.A. Kuster, and B.J. Luyet. 1975. Freeze-fixation at high subzero temperatures. Cryobiology 12:427-439.

Malone, S.R. and E.N. Ashworth. 1991. Freezing stress response in woody tissues observed using low-temperature scanning electron microscopy and freeze substitution techniques. Plant Physiol. 95:871-881.

Marini, R.P. and B.R. Boyce. 1977. Susceptibility of crown tissues of 'Catskill' strawberry plants to low temperature injury. J. Amer. Soc. Hort. Sci. 102:515-516.

Marini, R.P. and B.R. Boyce. 1979. Influence of low temperatures during dormancy on growth and development of 'Catskill' strawberry plants. J. Amer. Soc. Hort. Sci. 104:159-162.

Olien, C.R. 1964. Freezing processes in the crown of 'Hudson' barley, Hordeum vulgare (L., emend. Lam.) Hudson. Crop Sci. 4:91-95.

Pearce, R.S. 1988. Extracellular ice and cell shape in frost-stressed cereal leaves: A low-temperature scanning-electron-microscopy study. Planta 175:313-324.

Pearce, R.S. and E.N. Ashworth. 1992. Cell shape and localisation of ice in leaves of overwintering wheat during frost stress in the field. Planta 188:324-331.

Quamme, H.A. 1978. Mechanism of supercooling in overwintering peach flower buds. J. Amer. Soc. Hort. Sci. 103:57-61.

Quamme, H.A. and L.V. Gusta. 1987. Relationship of ice nucleation and water status to freezing patterns in dormant peach flower buds. HortScience 22:465-467.

Warmund, M.R. and W.K. Ki. 1992. Fluctuating temperatures and root moisture content affect survival and regrowth of cold-stressed strawberry crowns. Adv. Strawberry Res. 11:40-46.

Warmund, M.R., F. Takeda, and G.A. Davis. 1992. Supercooling and extracellular ice formation in differentiating buds of eastern thornless blackberry. J. Amer. Soc. Hort. Sci. 117:941-945.

Wiegand, K.M. 1906. Some studies regarding the biology of buds and twigs in winter. Bot. Gaz. 41:373-424.

Zurawicz, E. and C. Stushnoff. 1977. Influence of nutrition on cold tolerance of 'Redcoat' strawberries. J. Amer. Soc. Hort. Sci. 102:342-346. 